\title{
Implementasi in House Training untuk Meningkatkan Kemampuan Guru dalam Menetapkan Kriteria Ketuntasan Minimal
}

\author{
Solikhan \\ UPT SD Negeri Krisik 02, Gandusari Blitar, Indonesia \\ Email: iffahshalihan@gmail.com
}

\begin{abstract}
Abstrak: Kemampuan guru UPT SD Negeri Krisik 02, Gandusari dalam menentukan Kriteria Ketuntasan Minimal (KKM) sesuai ketentuan dan mekanisme yang berlaku masih rendah. Kegiatan In House Training (IHT) dapat meningkatkan kemampuan guru dalam menentukan Kriteria Ketuntasan Minimal sesuai ketentuan dan prosedur yang berlaku. Penelitian dilaksanakan secara kolaboratif dan dilakukan dalam 2 siklus, dua pertemuan tiap siklusnya. Masing-masing siklus tersebut terdiri dari tahap (1) perencanaan, (2) pelaksanaan, (3) pengamatan, dan (4) refleksi. Subyek penelitian guru UPT SD Negeri Krisik 02, Gandusari. Jenis analisis data dalam penelitian adalah statistik deskripstif, dengan teknik menggunakan
\end{abstract}

\begin{tabular}{l}
\hline Tersedia Online di \\
\hline http://journal.unublitar.ac.id/pendidik \\
an/index.php/Riset_Konseptual \\
\hline Sejarah Artikel \\
Diterima pada : 16-03-2020 \\
Disetuji pada : 24-04-2020 \\
Dipublikasikan pada $: 30-04-2020$ \\
\hline
\end{tabular}

\section{Kata Kunci:}

In house training, KKM, Guru SD

DOI:

http://doi.org/10.28926/riset_konseptual.v4i2. 207

presentase $(\%)$ pencapaian dengan konstanta 100. Berdasarkan data hasil pengamatan, hasil penilaian kerja peserta pelatihan, dan respon yang diberikan peserta pelatihan, analisis data menunjukkan bahwa dengan penerapan In House Training (IHT) yang mengacu pada tahapan atau fase pelaksanaan pelatihan Dessler (1997) kemampuan guru dalam menentukan KKM sesuai ketentuan dan prosedur yang berlaku meningkat, dari capaian nilai rata-rata penetapan KKM yang dibuat pada siklus pertama 71,88 \% menjadi $100,00 \%$ pada siklus kedua. Hal ini menunjukkan bahwa kegiatan In House Training (IHT) dengan mengacu pada tahapan atau fase pelaksanaan pelatihan Dessler (1997) dapat meningkatkan kemampuan guru UPT SD Negeri Krisik 02, Gandusari dalam menentukan Kriteria Ketuntasan Minimal (KKM) sesuai dengan ketentuan dan mekanisme yang berlaku.

\section{PENDAHULUAN}

Kompetensi pedagogik merupakan kemampuan guru dalam hal pemahaman terhadap peserta didik, perancangan dan pelaksanaan pembelajaran, evaluasi hasil belajar, dan pengembangan peserta didik untuk mengaktualisasikan berbagai potensi yang dimilikinya. Salah satu indikator pengukuran kompetensi pedagogik guru berdasarkan Permendiknas No. 16 Tahun 2007 (Depdiknas, 2007), mengembangkan kurikulum yang terkait dengan bidang pengembangan yang diampu. Kemampuan guru dalam menentukan Kriteria Ketuntasan Minimal (KKM) pada awal tahun pelajaran merupakan salah satu petunjuk bahwa guru tersebut telah mampu mengembangkan kurikulum pada satuan pendidikannya. Fungsi Kriteria Ketuntasan Minimal (KKM) antara lain sebagai acuan bagi pendidik dalam menilai kompetensi peserta didik sesuai kompetensi dasar mata pelajaran yang diikuti (Depdiknas, 2003). Maka, menjadi sangat penting seorang guru mampu menentukan Kriteria Ketuntasan Minimal (KKM) sesuai ketentuan dan mekanisme yang berlaku.

Standar penilaian pendidikan mewajibkan setiap guru untuk menentukan kriteria ketuntasan minimal (KKM) dengan memperhatikan karakteristik peserta didik, karakteristik mata pelajaran, dan kondisi satuan pendidikan, sebagaimana tersebut 
dalam Permendiknas No. 20 tahun 2007 (Depdiknas, 2007). Menetapkan KKM tiap muatan atau mata pelajaran pada awal tahun pelajaran merupakan tahap awal pelaksanaan penilaian hasil belajar sebagai bagian tak terpisahkan dari pengembangan Kurikulum Tingkat Satuan Pendidikan (KTSP). Untuk bisa ditetapkan sebagai patokan pencapaian ketuntasan belajar, maka KKM yang dibuat oleh seorang guru harus memenuhi standar yang telah disepakati oleh lembaga dimana seorang guru mengajar.

Berdasarkan hasil supervisi akademik, tentang penetapan Kriteria Ketuntasan Minimal pada awal tahun pelajaran 2019/2020 terhadap lima guru kelas dan tiga guru mata pelajaran UPT SD Negeri Krisik 02, Gandusari, diperoleh data 1 orang (12,5\%) kategori baik, 3 orang $(37,5 \%)$ kategori cukup, dan 4 orang $(50 \%)$ pada kategori kurang. Kondisi ini tentunya sangat jauh dari standar yang ditetapkan oleh lembaga UPT SD Negeri Krisik 02, Gandusari bahwa seluruh guru (100\%) harus mampu menetapkan KKM muatan atau mata pelajaran sesuai dengan ketentuan dan mekanisme yang berlaku, dan nilai yang diperoleh termasuk dalam kategori sangat baik. Dampaknya, tentunya KKM tersebut belum dapat dijadikan patokan pencapaian ketuntasan belajar pada tahun pelajaran 2019/2020.

Rendahnya kemampuan guru dalam menetapkan KKM tersebut, disebabkan karena adanya sebab dari diri guru yang bersangkutan dan juga dari lingkungan dimana mereka bekerja. Hasil wawancara menunjukkan sebagian besar guru berpandangan KKM muatan atau mata pelajaran dan KKM satuan pendidikan bukan menjadi sesuatu yang urgen dibuat pada awal tahun pelajaran, sehingga para guru enggan mencari referensi atau buku sumber berkaitan dengan KKM dan belum bersungguh-sungguh menetapkan KKM sebagaimana ketentuan dan mekanisme yang ada. Ketiadaan buku referensi berkaitan dengan KKM di sekolah, serta sikap kepala sekolah (peneliti) yang mempercayakan penetapan KKM kepada guru tanpa diikuti pendampingan dan praktik langsung juga menjadi penyebab rendahnya kemampuan para guru dalam menetapkan KKM sesuai dengan mekanisme dan ketentuan yang berlaku.

Solusi untuk untuk meningkatkan kemampuan guru UPT SD Negeri Krisik 02, Gandusari dalam menetapkan KKM muatan atau mata pelajaran dan KKM satuan pendidikan adalah dengan kegiatan In House Training. Beberapa penelitian terdahulu, dengan In House Training terbukti mampu meningkatkan kemampuan atau kompetensi tertentu dari sekelompok orang atau karyawan. Penelitian yang telah dilakukan Tarman (2019) menunjukkan bahwa kegiatan In House Training mampu meningkatkan minat dan kemampuan menetapkan Kriteria Ketuntasan Minimal pada guru SD Negeri 2 Mangunharjo, Wonogiri semester I tahun pelajaran 2018/2019. Minat guru dari $12,5 \%$ pada prasiklus menjadi $50 \%$ pada siklus I, dan meningkat $87,5 \%$ pada akhir siklus II. Nilai kemampuan guru dalam menetapkan KKM juga meningkat, dari nilai rata-rata pada prasiklus 68 , setelah dilaksanakan siklus I menjadi 76, sedangkan setelah siklus II dilaksanakan menjadi 84.

Penelitian lain yang dilakukan oleh Corinorita (2017) menunjukkan pula bahwa pelaksanaan kegiatan In House Training dapat meningkatkan kompetensi guru di dalam menyusun Rencana Pelaksanaan Pembelajaran di SMP Negeri 32 Pekanbaru tahun pelajaran 2015/2016. Pada siklus I kompetensi guru di dalam menyusun RPP adalah 71.3 dengan $50 \%$ guru yang telah dapat menyusun RPP dengan baik dan benar. Akhirnya pada siklus II kompetensi guru di dalam menyusun RPP adalah 87.8 dengan $100 \%$ guru yang telah dapat menyusun RPP dengan baik dan benar.

In House Training (Danim, 2012) merupakan pelatihan yang dilaksanakan secara internal oleh kelompok kerja guru, sekolah atau tempat lain yang ditetapkan sebagai penyelenggaraan pelatihan yang dilakukan berdasar pada pemikiran bahwa sebagian kemampuan dalam meningkatkan kompetensi dan karier guru tidak harus dilakukan secara eksternal, namun dapat dilakukan secara internal oleh guru sebagai trainer yang memiliki kompetensi yang belum dimiliki oleh guru lain. Kegiatan In House Training (IHT) dalam penelitian ini bertujuan untuk 
membantu meningkatkan kompetensi guru dalam menentukan Kriteria Ketuntasan Minimal (KKM) muatan atau mata pelajaran tertentu sesuai dengan ketentuan dan mekanisme yang berlaku.

In House Training dilaksanakan dalam tiga fase kegiatan, yakni perencanaan, proses pelaksanaan, dan evaluasi pelatihan. Fase proses pelaksanaan dibagi menjadi dua tahapan yaitu tahap persiapan dan tahap pelaksanaan pelatihan. Pada tahap persiapan proses pelatihan diantaranya meliputi: mempersiapkan kelengkapan bahan pelatihan (undangan pemberitahuan, materi, jadwal, media, daftar hadir, instrumen evaluasi) dan kesiapan sarana prasarana (tempat, fasilitas, konsumsi, peserta maupun trainer) (Nawawi, 2008).

Pada tahap pelaksanaan pelatihan, melalui alur: (1) mencairkan suasana agar peserta pelatihan merasa santai, (2) menjelaskan tujuan pelatihan, (3) memotivasi peserta untuk bertanya, (4) mengakrabkan guru dengan alat peraga/media yang digunakan dalam pelatihan, (5) menjelaskan pembelajaran yang berkualitas, (6) trainer menyampaikan materi dan memperagakan secara sistematis tentang penggunaan alat peraga/media yang digunakan dalam pelatihan secara perlahan, (7) trainer mengulang peragaan dan menjelaskan titik kunci, (8) trainer meminta peserta pelatihan untuk menjelaskan penggunaan alat peraga/media pembelajaran secara sistematis, (9) trainer membimbing peserta dalam uji coba peragaan penggunaan alat peraga pembelajaran secara bertahap untuk membangun keterampilan, (10) perserta mendemonstrasikan kemampuan dalam penggunaan alat peraga secara mandiri, dan (11) memberikan pujian untuk peserta yang dapat mendemonstrasikan dengan baik (Dessler, 1997).

Dalam penelitian ini, kegiatan In House Training (IHT) untuk meningkatkan kemampuan Guru UPT SD Negeri Krisik 02, Gandusari dalam menetapkan Kriteria Ketuntasan Minimal muatan atau mata pelajaran dilakukan dengan memfokuskan hasil penelitian pada 4 (empat) aspek target keberhasilan penelitian, yaitu (1) aspek proses pelaksanaan penelitian, (2) aspek pengetahuan dari peserta pelatihan, (3) aspek keterampilan peserta pelatihan, dan (4) aspek sikap peserta pelatihan. Masing-masing aspek tersebut mempunyai standar atau target ketuntasan tersendiri. Khusus pada aspek pengetahuan dan sikap dibedakan menjadi target secara individu dan klasikal. Penelitian ini dilakukan dengan tujuan untuk: (1) mendeskripsikan penerapan kegiatan In House Training untuk meningkatkan kemampuan guru dalam menetapkan Kriteria Ketuntasan Minimal pada Guru UPT SD Negeri Krisik 02, Gandusari Kabupaten Blitar, dan (2) mendeskripsikan peningkatan kemampuan guru dalam menetapkan Kriteria Ketuntasan Minimal setelah dilakukan kegiatan In House Training pada Guru UPT SD Negeri Krisik 02, Gandusari Kabupaten Blitar. Dengan adanya penelitian ini pula diharapkan dapat memberikan manfaat kepada peneliti sendiri, guru, siswa, dan peneliti lain.

\section{METODE}

Penelitian ini dilaksanakan di UPT SD Negeri Krisik 02, Gandusari Kabupaten Blitar. Tindakan penelitian dilaksanakan pada hari Khamis tanggal 14 dan 21 Nopember 2019. Penelitian dilaksanakan selama dua siklus, terdiri dari dua kali sesi atau pertemuan dalam setiap siklusnya. Subjek penelitian ini adalah delapan (8) guru UPT SD Negeri Krisik 02, Gandusari Kabupaten Blitar tahun pelajaran 2019/2020, terdiri dari lima guru kelas dan tiga guru mata pelajaran. Narasumber sebagai teman kolaboratif peneliti, juga menjadi subyek penelitian. Sedang peneliti, dalam hal ini bertindak selaku observer. Penelitian ini termasuk Penelitian Tindakan Kelas (Class Action Research).

Penelitian ini merupakan proses pengkajian sistem berdaur sebagaimana kerangka berpikir yang dikembangkan oleh Suharsimi Arikunto (2010). Prosedur ini mencakup tahap-tahap: (1) perencanaan, (2) pelaksanaan, (3) pengamatan, dan (4) refleksi. Tahapan tindakan tersebut mengacu pada prosedur penelitian berdasarkan 
prinsip Kemmis dan Mc Taggart (dalam Arikunto, 2010) sebagaimana tampak pada gambar berikut.

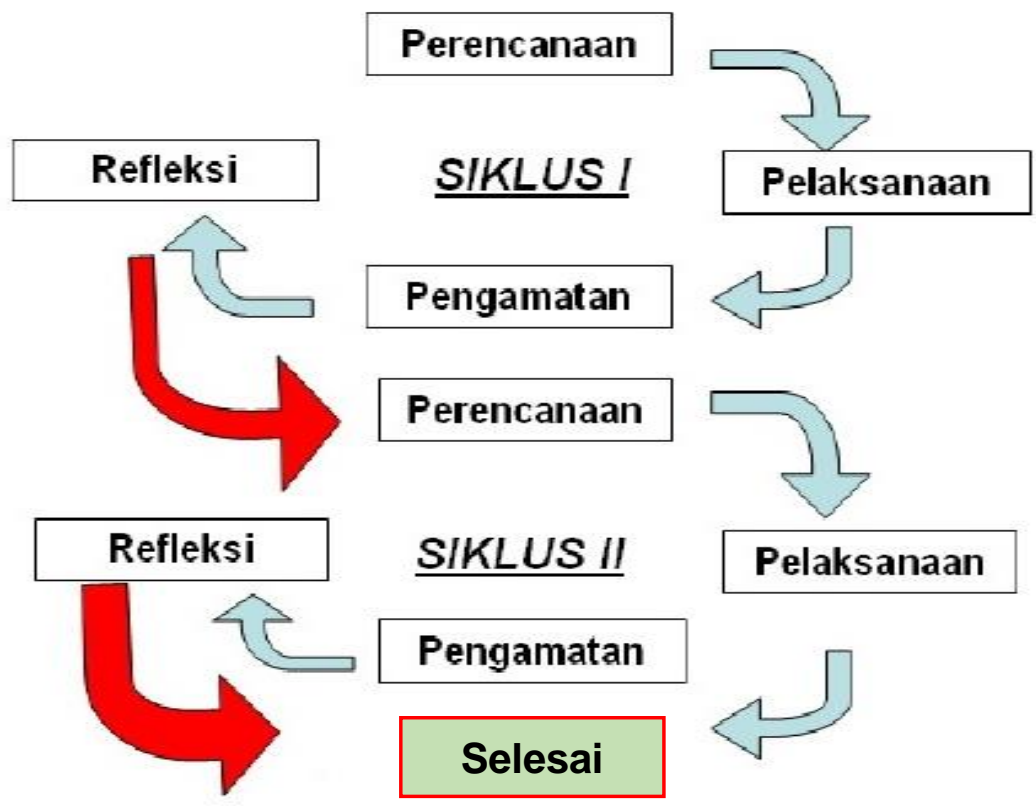

Gambar 1 Alur Penelitian Tindakan Kelas

Kriteria keberhasilan sebagai indikator bahwa penelitian telah mencapai target tindakan adalah: (1) aspek proses pelaksanaan kegiatan In House Training termasuk dalam kategori sangat baik, (2) aspek pengetahuan, seluruh peserta memperoleh nilai kategori sangat baik, baik secara individu mupun klasikal, (3) aspek keterampilan, seluruh peserta: (a) 100 \% telah mampu menetapkan KKM sesuai dengan ketentuan dan mekanisme yang berlaku dan (b) $100 \%$ peserta telah memperoleh nilai kategori sangat baik dan (4) aspek sikap, seluruh peserta telah memberikan respon positif terhadap pelaksanaan In House Training kategori sangat baik, secara individual maupun klasikal.

Pengumpulan data pada penelitian ini dengan menggunakan beberapa instrumen penelitian, yaitu Rancangan Kegiatan IHT, Lembar Kerja, Lembar Observasi Pelaksanaan IHT, Pedoman Penilaian Penetapan KKM, Lembar Kuesioner Kegiatan IHT, dan Lembar Soal. Rancangan Kegiatan In House Training mengacu pada proses pelaksanaan pelatihan menurut Dessler (1997). Sedangkan Lembar Observasi Pelaksanaan IHT dan Lembar Kuesioner Kegiatan IHT, peserta mengisi instrument tersebut dengan memberi tanda cheklis $(\sqrt{ })$. Sangat Tidak Setuju (skor 1), Tidak Setuju (skor 2), Setuju (skor 3), dan Sangat Setuju (skor 4). Setelah data terkumpul, maka dilakukan analisis data.

Jenis analisis data yang digunakan dalam penelitian ini adalah statistik deskripstif. Statistik deskriptif meliputi perhitungan mean, modus dan median sedangkan penyajian data menggunakan tabel atau grafik (Sugiyono, 2013). Tabel merupakan sajian data yang digunakan dalam penelitian untuk melihat peningkatan variabel dari siklus pertama ke siklus kedua. Penelitian ini menggunakan perhitungan rata-rata untuk mengetahui peningkatan proses pelaksanaan IHT, hasil penilaian penentuan KKM, respon atas pelaksanaan IHT, juga hasil tes peserta pelatihan. Mean adalah rata-rata hitung dengan membagi semua skor dengan jumlah peserta (Masidjo, 2010).

Teknik analisis data untuk melihat peningkatan target penelitian dilakukan secara berbeda sesuai dengan target yang diteliti. Secara umum analisis peningkatan proses pelaksanaan $\mathrm{IHT}$, hasil penilaian penentuan $\mathrm{KKM}$, respon atas pelaksanaan 
$\mathrm{IHT}$, dan hasil tes yang dilakukan peserta dengan perhitungan presentase perindikator, digunakan rumus berikut.

$$
\text { Hasil Penelitian }=\frac{\text { skoryang diperoleh peserta }}{\text { skor maksimal }} \times 100 \%
$$

Rumus di atas digunakan untuk menentukan besarnya presentase aspek proses pelaksanaan kegiatan In House Training (IHT), pengetahuan (hasil tes) peserta pelatihan, hasil penilaian penentuan KKM peserta pelatihan, serta respon peserta pelatihan terhadap pelaksanaan In House Training (IHT), apakah termasuk dalam kategori sangat baik, baik, cukup, atau kurang.

Adapun pedoman kualifikasi target penelitian, sebagaimana tersebut di atas adalah dengan menggunakan dasar kualifikasi standar kualifikasi guru (Depdiknas (2007) seperti tersebut pada tabel berikut.

Tabel 1 Pedoman Kualifikasi Target Penelitian

\begin{tabular}{cc}
\hline Target Penelitian $(\ldots \%)$ & Kualifikasi atau Kriteria \\
\hline $89<\mathrm{A} \leq 100$ & Sangat Baik \\
\hline $75<\mathrm{B} \leq 89$ & Baik \\
\hline $54<\mathrm{C} \leq 75$ & Cukup \\
\hline $0 \leq \mathrm{D} \leq 54$ & Kurang
\end{tabular}

\section{Deskripsi siklus satu}

\section{HASIL DAN PEMBAHASAN}

Siklus pertama Penelitian Tindakan Sekolah ini dilaksanakan pada hari Khamis tanggal 14 Nopember 2019 di UPT SD Negeri Krisik 02, Gandusari. Kegiatan In House Training (IHT) siklus pertama ini dalam satu saat dilaksanakan dua sesi atau pertemuan, yang dipisahkan oleh waktu istirahat. Hasil pengumpulan dan pengolahan data, telah ada perubahan cukup berarti dari peserta pelatihan terkait dengan pengetahuan, keterampilan, dan sikap bagaimana menentukan Kriteria Ketuntasan Minimal (KKM) sesuai dengan mekanisme dan ketentuan yang berlaku.

\section{Pelaksanaan In House Training (IHT)}

Hasil observasi kegiatan In House Training (IHT), diperoleh skor rata-rata proses pelaksanaan kegiatan In House Training (IHT), dengan fokus observasi aktifitas kegiatan yang telah dilakukan oleh narasumber pada saat siklus pertama adalah 3,27. Adapun persentase rata - rata proses pelaksanaan kegiatan adalah sebesar 81,82 \%, kategori baik. Lembar Kerja yang dikerjakan mata pelajarannya sama untuk seluruh peserta.

Pada pertemuan pertama, Lembar Kerja dikerjakan secara berkelompok. Sedang pada pertemuan kedua dikerjakan secara individu. Lembar Kerja muatan pelajaran IImu Pengetahuan Alam dikerjakan secara berkelompok, 2 - 3 orang tiap kelompok. Sedang muatan pelajaran Bahasa Indonesia, Lembar Kerjanya dikerjakan secara individu.

\section{Tes Awal Kegiatan In House Training (IHT)}

Hasil tes awal, dari delapan peserta kegiatan In House Training (IHT), hanya satu peserta $(12,50 \%)$ yang memperoleh nilai tes kategori sangat baik. Sisanya, empat peserta $(50,00 \%)$ kategori baik dan tiga peserta $(37,50 \%)$ kategori cukup. Secara klasikal, diperoleh rata - rata persentase hasil tes awal sebesar 76,25\%, kategori baik.

Tes awal dilakukan dengan tujuan untuk mengetahui sejauh mana pengetahuan awal tenaga pendidik UPT SD Negeri Krisik 02, Gandusari terkait dengan materi 
Menentukan Kriteria Ketuntasan Minimal (KKM) muatan atau mata pelajaran sesuai dengan ketentuan dan tahapan yang berlaku.

\section{Penentuan Kriteria Ketuntasan Minimal (KKM).}

Hasil penetapan KKM menunjukkan bahwa dari delapan peserta kegiatan IHT, baru satu peserta $(12,50 \%)$ yang mampu menentukan KKM muatan atau mata pelajaran sesuai dengan ketentuan dan prosedur yang berlaku dalam kategori sangat baik. Selebihnya, satu peserta $(12,50 \%)$ termasuk kategori baik dan enam peserta $(75,00 \%)$ dalam kategori baik. Rata - rata persentasenya adalah 71,88 \%, kategori cukup.

Dari lima item penilaian hasil penetapan atau penentuan KKM muatan atau mata pelajaran, baru satu item penilaian $(20,00 \%)$ yang termasuk kategori sangat baik. Sisanya, dua item $(40,00 \%)$ termasuk kategori baik, satu item $(20,00 \%)$ kategori cukup, dan satu item $(20,00 \%)$ kategori kurang.

\section{Kuesioner Pelaksanaan In House Training (IHT)}

Respon peserta terhadap pelaksanaan kegiatan In House Training (IHT) dilakukan dengan cara mengisi lembar kuisioner yang terdiri dari sepuluh (10) butir pernyataan. Dari delapan peserta terdapat dua orang $(25,00 \%)$ yang memberikan respon pelaksanaan kegiatan In House Training kategori sangat baik dan enam orang ( $75,00 \%$ ) memberikan respon kategori baik. Secara klasikal, rata-rata persentase tanggapan peserta atas kegiatan In House Training (IHT) ini adalah 85,00\%, kategori baik.

Membandingkan refleksi hasil penelitian siklus pertama dengan indikator keberhasilan atau ketuntasan penelitian, dapat disimpulkan bahwa tindakan penelitian pada siklus pertama ini belum memenuhi kriteria atau indikator keberhasilan tindakan penelitian. Sehingga perlu dilanjutkan dengan tindakan penelitian atau perbaikan siklus selanjutnya, yakni siklus kedua.

\section{Deskripsi siklus dua}

Siklus kedua Penelitian Tindakan Sekolah ini dilaksanakan pada hari Khamis tanggal 21 Nopember 2019 di UPT SD Negeri Krisik 02, Gandusari. Kegiatan In House Training (IHT) siklus kedua dilaksanakan dengan memperbaiki kualitas pelaksanaan kegiatan serta Lembar Kerja yang digunakan. Lembar Kerja yang digunakan dibuat berbeda untuk tiap jenjang kelas dan berbeda untuk tagihan tugas secara berkelompok maupun secara individu. Hasil pengumpulan dan pengolahan data, telah ada perubahan sangat luar biasa dari peserta pelatihan terkait dengan pengetahuan, keterampilan, dan sikap bagaimana menentukan Kriteria Ketuntasan Minimal (KKM) sesuai dengan mekanisme dan ketentuan yang berlaku.

\section{Pelaksanaan In House Training (IHT)}

Skor rata-rata proses pelaksanaan kegiatan In House Training (IHT), dengan fokus observasi aktifitas kegiatan yang telah dilakukan oleh narasumber pada saat siklus kedua adalah 3,82 . Persentase rata - rata proses pelaksanaan kegiatan In House Training (IHT) adalah sebesar 95,45 \%, termasuk kategori sangat baik. Peserta, baik secara kelompok atau individu diberikan pilihan Lembar Kerja yang berbeda mata pelajarannya.

Satu Lembar Kerja untuk dikerjakan secara berkelompok, satu Lembar Kerja lagi untuk dikerjakan secara individual pada sesi atau pertemuan kedua. Jenjang kelas I, II, dan III disiapkan Lembar Kerja muatan pelajaran Matematika dan PPKn. Sedang untuk jenjang kelas IV, V, dan VI disiapkan Lembar Kerja mata pelajaran Matematika dan Ilmu Pengetahuan Sosial. 


\section{Tes Akhir Kegiatan In House Training (IHT)}

Mengakhiri pelaksanaan kegiatan In House Training (IHT) siklus kedua, dilakukan kegiatan post test atau tes akhir. Dari delapan peserta kegiatan In House Training, semuanya $(100,00 \%)$ telah berhasil mencapai nilai tes kategori sangat baiak. Secara klasikal, diperoleh rata - rata persentase hasil tes akhir adalah sebesar 95,00 $\%$, kategori sangat baik.

\section{Penentuan Kriteria Ketuntasan Minimal (KKM)}

Hasil penentuan Kriteria Ketuntasan Minimal (KKM), delapan peserta kegiatan In House Training, seluruhnya $(100,00 \%)$ telah mampu menentukan KKM muatan atau mata pelajaran sesuai dengan ketentuan dan prosedur yang berlaku dan termasuk dalam kategori sangat baik. Demikian pula, Lima item penilaian hasil penetapan atau penentuan KKM muatan atau mata pelajaran peserta kegiatan In House Training, seluruhnya $(100,00 \%)$ juga telah termasuk kategori sangat baik.

\section{Kuesioner Pelaksanaan In House Training (IHT)}

Respon yang diberikan oleh peserta kegiatan In House Training (IHT) adalah delapan peserta, seluruhnya $(100,00 \%)$ telah memberikan respon pelaksanaan kegiatan In House Training kategori sangat baik. Secara klasikal, rata-rata persentase tanggapan peserta atas kegiatan In House Training (IHT) ini adalah 94,69\%, kategori sangat baik.

Membandingkan hasil penelitian siklus kedua ini dengan indikator keberhasilan atau ketuntasan penelitian tersebut di atas, dapat disimpulkan bahwa tindakan penelitian pada siklus kedua telah memenuhi kriteria atau indikator keberhasilan tindakan penelitian. Sehingga tidak perlu lagi dilanjutkan dengan tindakan penelitian atau perbaikan siklus selanjutnya, atau siklus ketiga.

\section{Deskripsi perubahan siklus satu dan siklus dua Pelaksanaan In House Training (IHT)}

Hampir semua butir observasi proses pelaksanaan In House Training (IHT) telah mengalami peningkatan pada siklus kedua. Kecuali pada butir ke-8 tidak mengalami perubahan, tetap bernilai 3 (setuju). Sebaliknya, pada butir ke-3 terjadi penurunan hasil dari nilai observasi 4 menjadi 3.

Demikian pula skor rata-rata pelaksanaan kegiatan In House Training (IHT) telah mengalami peningkatan pada siklus kedua. Dari skor rata-rata 3,27 pada siklus pertama naik menjadi 3,82 pada siklus kedua.

\section{Tes Kegiatan In House Training (IHT)}

Hasil tes yang diperoleh oleh peserta kegiatan In House Training (IHT) ini pada umumnya telah mengalami peningkatan kualitas pada siklus kedua. Peningkatan persentase kualitas atau skor tersebut terjadi baik secara klasikal maupun individual.

Secara klasikal persentase rata-rata terjadi peningkatan dari 76,25 \% (kategori baik) pada siklus pertama menjadi 95,00 \% (kategori sangat baik) pada siklus kedua. Secara invidual, delapan tenaga pendidik UPT SD Negeri Krisik 02, Gandusari, peserta kegiatan ini seluruhnya $(100,00 \%)$ sudah berhasil menaikkan persentase perolehan skor tes pada siklus kedua. Persentase skor perolehan peserta dimaksud seluruhnya dalam kategori sangat baik.

\section{Penentuan Kriteria Ketuntasan Minimal (KKM)}

Hasil penilaian penentuan Kriteria Ketuntasan Minimal (KKM) muatan atau mata pelajaran oleh delapan (8) tenaga pendidik UPT SD Negeri Krisik 02, Gandusari baik secara klasikal maupun individual pada siklus kedua telah mencapai hasil yang ditargetkan, yakni kategori sangat baik.

Secara klasikal, pada siklus kedua dari lima butir penilaian hasil penetapan Kriteria Ketuntasan Minimal (KKM) seluruh persentasenya adalah 100,00 \% (kategori 
sangat baik), setelah pada siklus pertama hanya pada butir penilaian ke-2 yang memperoleh persentase $100,00 \%$ (kategori sangat baik). Demikian pula, untuk ratarata persentase telah diperoleh persentase 100,00 \% (kategori sangat baik) setelah hanya diperoleh $71,88 \%$ (kategori cukup) pada siklus pertama.

Secara individual, berdasarkan penilaian hasil penetapan Kriteria Ketuntasan Minimal (KKM), delapan (8) tenaga pendidik UPT SD Negeri Krisik 02, Gandusari pada siklus kedua seluruhnya telah mampu mencapai hasil target kegiatan, yakni persentase skor $100,00 \%$ (kategori sangat baik). Dimana pada siklus pertama hanya ada satu peserta kegiatan yang berhasil memperoleh persentase skor 100,00 \%.

\section{Kuesioner Pelaksanaan In House Training (IHT)}

Secara klasikal, pada siklus kedua dari sepuluh butir pernyataan kuisioner pelaksanaan kegiatan In House Training seluruh persentasenya mengalami kenaikan yang cukup berarti. Sembilan (9) butir pernyataan dalam kategori sangat baik, satu (1) butir pernyataan kategori baik. Dari sembilan (9) butir pernyataan tersebut, butir ke-2, ke-3, ke-4, dan ke-9 mendapatkan respon sempurna (100,00 \%). Untuk rata-rata persentase diperoleh persentase $94,60 \%$ (kategori sangat baik) setelah pada siklus pertama diperoleh $85,00 \%$ (kategori baik).

Dilihat secara individual, berdasarkan penilaian hasil respon atau tanggapan terhadap pelaksanaan kegiatan In House Training (IHT), delapan (8) tenaga pendidik UPT SD Negeri Krisik 02, Gandusari pada siklus kedua seluruhnya memberikan tanggapan positif, yakni persentase skor kategori sangat baik. Dimana pada siklus sebelumnya, siklus pertama hanya dua peserta kegiatan yang memberikan respon kategori sangat baik atas kegiatan ini.

Tabel 2 Indikator Keberhasilan Penelitian dan Hasilnya

\begin{tabular}{lccccccc}
\hline & \multicolumn{5}{c}{ Aspek Indikator Keberhasilan Penelitian } \\
\cline { 2 - 7 } Target dan \\
Hasil Siklus & $\begin{array}{c}\text { Proses } \\
\text { Pelaksana } \\
\text { an }\end{array}$ & Individu & Klasikal & $\begin{array}{c}\text { KKM } \\
\text { Benar }\end{array}$ & $\begin{array}{c}\text { Kategori } \\
\text { Sangat } \\
\text { Baik }\end{array}$ & Individu & Klasikal \\
\cline { 2 - 7 } $\begin{array}{l}\text { Target } \\
\text { Tindakan }\end{array}$ & $\begin{array}{c}\text { Sangat } \\
\text { baik }\end{array}$ & $\begin{array}{c}\text { Sangat baik } \\
(100.00 \%)\end{array}$ & $\begin{array}{c}\text { Sangat } \\
\text { baik }\end{array}$ & $100.00 \%$ & $100.00 \%$ & $\begin{array}{c}\text { Sangat baik } \\
(100.00 \%)\end{array}$ & $\begin{array}{c}\text { Sangat } \\
\text { baik }\end{array}$ \\
\hline Siklus 1 & Baik & $12.50 \%$ & Baik & $12.50 \%$ & $12.50 \%$ & $25.00 \%$ & Baik \\
\hline Siklus 2 & $\begin{array}{c}\text { Sangat } \\
\text { baik }\end{array}$ & $100.00 \%$ & $\begin{array}{c}\text { Sangat } \\
\text { baik }\end{array}$ & $100.00 \%$ & $100.00 \%$ & $100.00 \%$ & $\begin{array}{c}\text { Sangat } \\
\text { baik }\end{array}$ \\
\hline
\end{tabular}

Dari tabel 2 tersebut di atas, deskripsi dari proses pelaksanaan In House Training (IHT), hasil tes kegiatan In House Training (IHT), hasil penilaian penentuan Kriteria Ketuntasan Minimal (KKM), dan hasil kuesioner pelaksanaan In House Training (IHT) siklus pertama dan siklus kedua di atas, menunjukkan bahwa telah terjadi perubahan data penelitian yang signifikan pada siklus kedua dibanding siklus pertama.

Aspek pelaksanaan In House Training (IHT) pada siklus kedua telah mencapai kriteria sangat baik, setelah pada siklus pertama termasuk kualifikasi baik. Pada aspek pengetahuan, yakni seberapa jauh pengetahuan peserta pelatihan tentang Penentuan Kriteria Ketuntasan Minimal muatan atau mata pelajaran, pada siklus kedua secara individual seluruh peserta (100\%) telah mencapai nilai kategori sangat baik, setelah pada siklus pertama hanya satu orang $(12,50 \%)$ yang mencapai nilai kategori sangat 
baik. Secara klasikal, presentase rata-rata pengetahuan peserta pelatihan pada siklus kedua tergolong sangat baik, setelah sebelumnya pada siklus pertama tergolong baik.

Pada aspek keterampilan, yaitu kemampuan peserta pelatihan menentukan KKM sesuai dengan ketentuan dan prosedur yang berlaku, pada siklus kedua semua peserta (100\%) telah mampu menentukan KKM muatan atau mata pelajaran dengan benar dan termasuk kategori sangat baik setelah pada siklus pertama hanya hanya satu orang $(12,50 \%)$ telah memenuhi target tindakan. Selanjutnya, pada aspek sikap yang ditandai dengan respon peserta terhadap pelaksanaan kegiatan In House Training (IHT), pada siklus kedua secara individual seluruh peserta (100\%) telah memberikan respon kategori sangat baik, setelah pada siklus pertama hanya dua orang $(25,00 \%)$ yang memberikan respon kategori sangat baik. Secara klasikal, presentase rata-rata respon peserta atas pelaksanaan pelatihan pada siklus kedua tergolong sangat baik, setelah sebelumnya pada siklus pertama tergolong baik.

Perubahan dan perolehan data tersebut menunjukkan bahwa seluruh indikator ketercapaian atau keberhasilan dalam penelitian yang telah ditetapkan sebelumnya sudah terpenuhi semuanya. Sehingga, tidak diperlukan lagi penelitian siklus berikutnya, atau siklus yang ketiga. Dengan berakhirnya penelitian ini, sudah memberikan sebuah gambaran bahwa dengan kegiatan In House Training (IHT) telah mampu meningkatkan kemampuan tenaga pendidik UPT SD Negeri Krisik 02, Gandusari untuk menentukan Kriteria Ketuntasan Minimal (KKM) muatan atau mata pelajaran yang diampu.

Hasil penelitian ini sesuai atau sama dengan hasil penelitian terdahulu yang telah dilakukan oleh Noriko Candra Khaerani, Guru SMP Negeri 3 Tirto, Pekalongan, Jawa Tengah bahwa melalui kegiatan IHT dapat meningkatkan kompetensi guru SMP Negeri 3 Tirto, Pekalongan dalam menyusun Rencana Pelaksanaan Pembelajaran (Khaerani, 2016). Begitu pula sesuai dengan hasil penelitian yang dilakukan oleh Corinorita, Guru SMP Negeri 32 Pekanbaru bahwa pelaksanaan In House Training dapat meningkatkan kompetensi guru di dalam menyusun rencana pelaksanaan pembelajaran di SMP Negeri 32 Pekanbaru tahun pelajaran 2015/2016 (Corinorita, 2017). Hasil penelitian yang dilakukan oleh Tarman, Kepala SD Negeri 2 Mangunharjo, Kabupaten Wonogiri juga menghasilkan kesimpulan bahwa terjadi perubahan kualitas proses menetapkan KKM melalui IHT untuk meningkatkan minat dan kemampuan menetapkan KKM pada guru SDN 2 Mangunharjo semester I tahun Pelajaran 2018/2019 (Tarman, 2019).

\section{KESIMPULAN}

Kesimpulan dari kegiatan Penelitian Tindakan Sekolah yang peneliti lakukan adalah: (1) Penerapan In House Training dalam upaya meningkatkan kemampuan guru UPT SD Negeri Krisik 02, Gandusari dalam menetapkan Kriteria Ketuntasan Minimal (KKM) sesuai dengan ketentuan dan mekanisme yang berlaku, dilaksanakan menurut tahapan atau fase Dessler (1997) yang dilakukan secara berkelompok dan invidual, dengan Lembar Kerja yang sama untuk seluruh peserta pada siklus pertama dan dengan Lembar Kerja yang berbeda sesuai dengan mata pelajaran dan jenjang kelas peserta pada siklus kedua, dan (2) Dengan kegiatan In House Training dapat meningkatkan kemampuan guru UPT SD Negeri Krisik 02, Gandusari dalam menetapkan Kriteria Ketuntasan minimal sesuai dengan ketentuan dan mekanisme yang berlaku. Hal ini dapat dilihat dari capaian nilai rata-rata penetapan KKM yang dibuat, pada siklus pertama 71,88 \% (cukup) menjadi 100,00 \% (sangat baik) pada siklus kedua, terjadi peningkatan $28,12 \%$.

Saran atas keberhasilan kegiatan Penelitian Tindakan Sekolah yang peneliti lakukan adalah: (1) Kepala Sekolah, termasuk peneliti terus berusaha membina dan memfasilitasi guru untuk meningkatkan kemampuan atau kompetensi pedagogiknya, (2) Guru, berusaha menetapkan Kriteria Ketuntasan Minimal (KKM) sesuai ketentuan dan mekanisme yang berlaku pada awal tahun pelajaran, (3) Secara tidak langsung, siswa berhak untuk memperoleh pelayanan terbaik dan maksimal dari gurunya, dan (4) Peneliti lain, terdorong melakukan penelitian sejenis di sekolah atau lembaga lain 
yang memiliki karakteristik yang relatif sama dengan menerapkan In House Training untuk meningkatkan kemampuan guru dalam menetapkan KKM dengan benar

\section{DAFTAR RUJUKAN}

Arikunto, Suharsimi. 2010. Prosedur Penelitian Suatu Pendekatan Praktik. Jakarta: PT Rineka Cipta

Coricorino. 2017. Pelaksanaan In House Training untuk Meningkatkan Kompetensi Guru dalam Menyusun RPP di Sekolah Menengah Pertama. Suara Guru: Jurnal Ilmu Pendidikan Sosial, sains, dan Humaniora Vol. 3 No. 1, Maret 2017

Danim. Sudarwan. 2012. Pengembangan Profesi Guru, dari Prajabatan, Induksi ke Professional Madani. Jakarta: Kencana Prenada Media

Depdiknas. 2007. Peraturan Menteri Pendidikan Nasional RI Nomor 16 Tahun 2007 tentang Standar Kualifikasi Akademik dan Kompetensi Guru. Jakarta: Depdiknas

Depdiknas. 2007. Peraturan Menteri Pendidikan Nasional RI Nomor 20 Tahun 2007 tentang Standar Penilaian. Jakarta: Depdiknas

Depdiknas. 2003. Undang-Undang Nomor 20 Tahun 2003 tentang Sistem Pendidikan Nasional. Jakarta: Depdiknas

Dessler, Gary. 1997. Manajemen Sumberdaya Manusia. Jakarta: PT. Prenhallindo

Khaerani, Noriko Candra. 2016. Peningkatan Kompetensi Guru dalam Menyusun RPP melalui Kegiatan IHT. Didaktikum: Jurnal Penelitian Tindakan Kelas Vol. 17, No. 1, Januari 2016

Masidjo, I. 2010. Penilaian Pencapaian Hasil Belajar Siswa. Jakarta: Kanisius

Nawawi, Hadari. 2008. Manajemen Sumber Daya Manusia. Jakarta: Ghalia Indonesia

Tarman. 2019. Upaya Meningkatkan Minat dan Kemampuan Menetapkan Kriteria Ketuntasan Minimal Melalui In House Training (IHT) pada Guru SD Negeri 2 Mangunharjo Tahun AJaran 2018/2019. Jurnal Penelitian Volume III, Nomor 3, Edisi Oktober 2019

Sugiyono. 2013. Metode Penelitian Kuantitatif, Kualitatif dan R \& D. Bandung: Alfabeta. 